The Wellcome Trust has given $£ 80,000$ for the extension of the College's Museum, and it has been decided to name one wing of the new building the "Sir Henry Wellcome Wing". Up to July 1945 the College had received $£ 122,000$ of the $£ 250,000$ required to complete the restoration and development of the College.

The staff of the Department of Anatomy has been strengthened by the appointment of Prof. F. Wood Jones to the Sir William H. Collins chair of human and comparative anatomy. This department also has been occupied with problems arising from the war-time dispersal of its specimens to institutions and private residences, where they have been well looked after. No new anatomical preparations have been made this session, but the report records the other work of the department and gives a list of the additions made to the anatomical, osteological, physiological, odontological and historical sections of the Museum and also additions to the collections of instruments.

The Bernhard Baron Research Laboratories, under the direction of Prof. John Beattie, has, during the past five years, made important contributions to the study of blood transfusion, the maintenance of constant blood volume and problems of blood dilution when hæmorrhage occurs. Prof. Beattie here gives a valuable brief review of this problem. It was found that, in fully hydrated subjects, the plasma protein concentration did not fall as the hæmoglobin concentration fell, and that protein was being added to the extravascular fluid which was entering the circulation to restore the blood volume. 'This added protein came partly from the liver and partly from the muscles. The plasma protein moved out of the circulation as rapidly as it entered it after hæmorrhage, or sometimes even more rapidly. There is therefore in normal persons a protein store which can be rapidly mobilized into the blood stream. Prof. Beattie discusses the rate of this protein synthesis, which determines how much protein can be lost from the body (in exudates from wounds or burns, for example) without loss of weight or hypo. proteinæmia. A study of this problem led to experiments, which are still in progress, on the intravenous administration of proteins, such as casein hydrolysates.

The problem of protein synthesis is also being attacked through the study of cases of infective hepatitis and allied diseases of the liver. People suffering from these diseases rapidly lose weight in the early phases, and the balance between intake and output of nitrogen is negative and accounts for practically all the loss of weight. A time comes, however, when the protein is again synthesized and retained; the nitrogen balance becomes positive and the excess of synthesis over destruction of protein can bo measured. Much information about the rate of protein synthesis has been obtained by these studies. The relationships between necrosis of the liver and severe trauma and cessation of healing have also been studied.

The bearing of this work on the importance of diet in surgical care was shown by studies in Holland after the liberation, when the grossly inadequate protein intakes before liberation prevented or delayed healing of wounds, so that surgical work was practically at a standstill. Within a fow weoks of increase of the protein ration and of the total caloric intake, surgical operations could again be undertaken. Supplementary feeding in the form of $100 \mathrm{gm}$. of protein daily given as predigested proteins rapidly speeded up wound healing and created a positive nitrogen balance. At the request of Supreme Headquarters, Netherlands, the Bernhard Baron Laboratories provided the nucleus of a laboratory team which went to Holland with the army of occupation to study the effects of long-continued deprivation of food in that country. A report on this work is being submitted to the Medical Research Council.

The laboratory has now returned to the Royal College of Surgeons. Dr. F. K. Sanders, Leverhulme Research Scholar at the Department of Zoology and Comparative Anatomy at Oxford, has continued his work on peripheral nerve injuries. G. LAPAGE.

\section{A FRENCH MESOLITHIC SITE}

$T$

HE rock-shelter of Cuzoul, near Gramat, is in the Lot (France). It is large in size, extending some $30 \mathrm{~m}$. by $17 \mathrm{~m}$. and $2 \frac{1}{2} \mathrm{~m}$. high. The excavators* have unearthed seven archæological levels separated from each other by thin sterile layers. Industries, mainly mesolithic in date and culture, have been collected as well as associated fauna and some human remains from levels 2,4 and 6 . Lovel 2 yielded a complete skeleton.

As regards the industries, microlithic implements of Tardenoisean facies occur throughout. But in levels 6 and 7 they are associated with other, later, types such as leaf-shaped arrow-heads; and actually, in level 7, with tanged and tanged-and-winged arrow-heads and some pottery. The authors assign the industry of level 1 to the Sauveterrien, that of levels 2 and 3 to an early Tardenoisean, that of 4 and 5 to a later Tardenoisean, and that of levels 6 and 7 to a final stage of the same culture. This may well be correct, but one would venture to suggest that, in time, these industries of the upper two levels are of a latish neolithic or even an early metal age date. Such overlaps between the latest phases of the mesolithic and later cultures are well known in Britain, especially in Scotland. Again, the industries from Mugem (Portugal) and Axpea (Spain), though culturally speaking they appear to be mainly mesolithic, must be contemparary with much more recent cultures elsewhere. Except for the more recent additions in the upper two levels the industries as a whole are fairly similar. There are blunted backs, burins of various types, notched blades, awls, disks, scrapers, etc. But it is true to say that the lower levels show more affinities with an upper palæolithic industry than do the later ones. A bone perforated object and some large bone awls as well as a small pierced shell came from level 2, the complete skeleton layer.

In many ways one can say that the publication is a model. After describing the situation and the stratigraphy, an account of the fauna found is given. Then follows a detailed description of the finds, level by level, concluding with a brief comparative table. Following this comes an account of the human remains found, comparisons being made with those from Téviec and Mugem. In conclusion, there are eight full-page plates. The authors are to be congratulated on a really excellent piece of work, well performed and well published. M. C. BuRkITr.

- Le gisement mésolithique du Cuzoul de Gramat. Par R. Lacam, A. Niederlender et $\mathbf{H}$.-V. Vallois. (Archives de l'Institut de Paléontologie humaine, Mémoire 21.) Pp. iii $+92+8$ plates. (Paris: Masson et Cie., 1944.) 220 francs. 